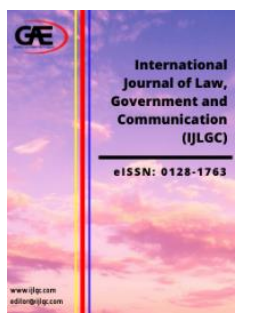

\author{
INTERNATIONAL JOURNAL OF LAW, \\ GOVERNMENT AND COMMUNICATION \\ (IJLGC) \\ $\underline{w w w . i j l g c . c o m}$
}

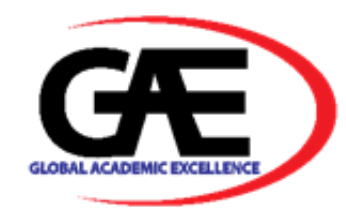

\title{
ELECTION DURING COVID-19 PANDEMIC: CONSTITUTIONAL PERSPECTIVES
}

\author{
Haslinda Mohd Anuar ${ }^{1 *}$ \\ 1 School of Law, Universiti Utara Malaysia, Malaysia. \\ Email: haslinda@uum.edu.my \\ * Corresponding Author
}

\section{Article Info:}

Article history:

Received date: 09.11.2020

Revised date: 15.11 .2020

Accepted date: 10.12 .2020

Published date: 31.12 .2020

\section{To cite this document:}

Anuar, H. M. (2020). Election During Covid-19 Pandemic: Constitutional Perspectives. International Journal of Law, Government and Communication, 5 (21), 277-284.

DOI: $10.35631 /$ IJLGC.5210023.

This work is licensed under $\underline{\mathrm{CC} B Y}$ 4.0

\begin{abstract}
:
The spread of Covid-19 requires a new norm in all aspects of life. To a democratic country, the conduct of an election is a must to ensure the system is in line with the rule of law. Malaysia announced her 'lockdown' on 18th March 2020 after the increase of the numbers of Covid-19 positive cases. Since then, three elections have been conducted. This paper aims to explore the constitutional provisions relating to elections and study the methods elections been conducted during the pandemic. To curb the spread of the Covid-19 virus, suggestions are made to tighten the Standard Operating Procedures (SOPs) and the last straw of proclaiming emergency. In conclusion, the constitutional provisions must be strictly complied with and cooperation from all walks of life is important to combat the pandemic.
\end{abstract}

Keywords:

Election, Covid-19, Pandemic, Constitution

\section{Introduction}

Covid-19 pandemic has affected mostly all activities all over the world. Due to the impact of the pandemic, Malaysia issued and announced the Movement Control Order (MCO) on $18^{\text {th }}$ March 2020. The announcement further limits the democracy process, that is, the election. Election process which requires mass gathering throughout its campaign periods and voting days, seems impracticable to abide the Standards Operating Procedures (SOPs) issued by the government in controlling the spread of the virus. Articles 55(3) and (4) of the Malaysia Federal Constitution requires the election to be conducted after 60 days of the dissolution of the legislature. Delaying or postponing the election infinitely is clearly inconsistent with the constitutional provisions. Armchair research or doctrinal research which is essentially a library- 


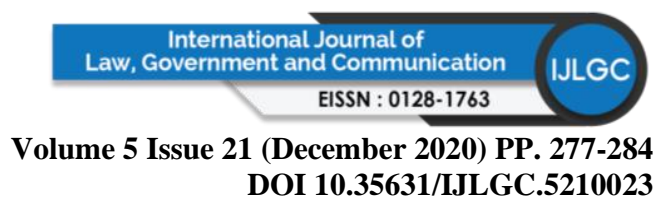

based research was used whereby the materials examined by the author were available in libraries, archives and other databases. The aim of such research is to discover, explain, examine, analyse and present, in a systematic form, facts, principles, provisions, concepts, theories or the working of certain laws or legal institutions (Anwarul Yakin, 2007). Using the arm-chair research methodology, this paper explores the constitutional provisions relating to election and study the past elections conducted during the covid-19 pandemic in Malaysia.

\section{Election in the Federal Constitution}

The Federal Constitution enumerates a few Articles relating to election. Under Part IV (The Federation), Chapter 4 (Federal Legislature), Article 55(3) and (4); and Part VIII (Elections), Articles 113 till 120.

Article 55 of the Federal Constitution vested the power to the Yang Di-Pertuan Agong to summon, prorogate and dissolve the Parliament. Article 55(1) provides, 'The Yang di-Pertuan Agong shall from time to time summon Parliament and shall not allow six months to elapse between the last sitting in one session and the date appointed for its first meeting in the next session'. Clause (2) states, 'The Yang di-Pertuan Agong may prorogue or dissolve Parliament'. Articles 55(3) provides that, "Parliament unless sooner dissolved, shall continue for five years from the date of its first meeting and shall then stand dissolved". Further Article 55(4) states, "Whenever Parliament is dissolved a general election shall be held within sixty days from the date of the dissolution and Parliament shall be summoned to meet on a date not later than one hundred and twenty days from that date" (The Federal Constitution).

Article 40(2) states, 'The Yang di-Pertuan Agong may act in his discretion in the performance of the following functions, that is to say: (b) the withholding of consent to a request for the dissolution of Parliament;' (The Federal Constitution).

Article 21(1) of The Constitution of the State of Sabah (The Sabah Constitution) provides that, 'The Yang di-Pertua Negeri may from time to time summon the Legislative Assembly, and shall not allow six months to elapse between the sitting in one session and the date appointed for its first sitting in the next session'. Article 21 (1) then states, 'The Yang di-Pertua may prorogue o dissolve the Legislative Assembly'. Clause (3) further provides, 'The Legislative Assembly shall, unless sooner dissolved, continue for five years from the date of its first sitting and shall then stand dissolved'. Clause (4) of Sabah Constitution states, 'Whenever the Legislative Assembly is dissolved, a general election shall be held within sixty days from the date of the dissolution and the new Legislative Assembly will be summoned to meet on a date not later than one hundred and twenty days from that date'. Article 21(5) further provides, 'Whenever the seat of an elected member has become vacant for any reason other than a dissolution, the vacancy shall, within sixty days from the date on which it is established that there is a vacancy, be filled by election in accordance with the provisions of this Constitution' (The Constitution of the State of Sabah).

The Constitution of the State of Sarawak has a similar Article 21 as the Sabah Constitution (The Constitution of the State of Sarawak).

These constitutional provisions clearly provide the maximum term for a parliamentary session, and the timeframe for summoning a sitting in a new session. 


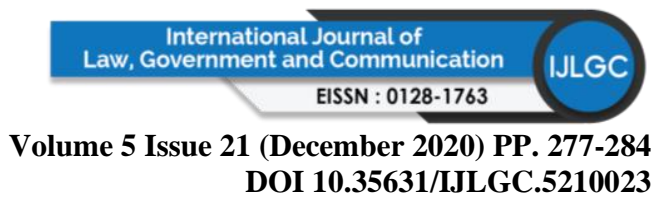

Part VIII of the Federal Constitution consists of nine Articles relating to election. Article 113 is on the conduct of elections. Article 113(1) states that, "There shall be an Election Commission (EC), to be constituted in accordance with Article 114, which subject to the provisions of federal law, shall conduct elections on the House of Representatives and the Legislative Assemblies of the States and prepare and revise electoral rolls for such election". Then, Article 114 on constitution of Election Commission; Article 115 on assistance to Election Commission; Article 116 on Federal constituencies; Article 117 on state constituencies; Article 118 on method of challenging election; Article 118A on method of questioning election petition of no return; Article 119 on qualifications of electors; and Article 120 on direct elections to the Senate (The Federal Constitution). These constitutional provisions are more on the conduct and procedures during the election.

\section{Lesson Learnt From Past Elections}

As to-date, three elections have been conducted since Malaysia announced the MCO. The first two by-elections were due because of the death of the member of Legislative Assemblies in Chini and Slim constituencies, and the other one was the state election due to political crises which led to the dissolution of Sabah state legislative assembly.

\section{Chini By-Election}

Chini state by-election on $4^{\text {th }}$ July 2020 was the first election conducted after Malaysia announced the Movement Control Order (MCO) in March 2020 (Bernama, 30 May 2020). There are 20,990 registered voters for the Chini by-election comprising 20,972 ordinary voters and 18 early voters. The EC issued a Press Statement dated 15 June 2020 on the special SOPs for the Chini by-election. It includes prohibition on procession in large group during nomination day, minimize the number of supporters in public gathering, allowing only one main operation room for each party, prohibition of walkabout campaign and encouraging online campaign via social media, and strict compliance to the SOP issued by Ministry of Health during the polling day (Suruhanjaya Pilihan Raya Malaysia, 15 June 2020). Second press statement was issued on 19 Jun 2020, to amend the earlier special SOPs. Some flexibilities were given by allowing the candidate and party to have public campaign with 250person capacity at one time, and walkabout campaign is allowed only for three persons at one time and place (Suruhanjaya Pilihan Raya Malaysia, 19 Jun 2020)

\section{Slim By-Election}

Slim by-election was held on 29 August 2020 with 23,094 registered voters comprising 22,815 normal voters, 277 early voters as well as 2 absentee voters overseas. The guidelines used during the Chini state seat by-election was used in the Slim by-election with some improvements to curb the spread of Covid-19. The EC issued a press statement of Covid-19 Prevention Guidelines for the Implementation of Election in Slim By-election on 14 August 2020. The content of guidelines issued is like SOPs during Chini by-election Suruhanjaya Pilihan Raya Malaysia, 14 August 2020).

This includes the party operations rooms and the smaller by-elections rooms which have been permitted opened during the by-election, including on polling day, subject to the SOPs set by the EC. The operations rooms must first be registered with the EC for monitoring purposes, the campaign and talks can only be conducted in enclosed or gated areas to facilitate monitoring and body temperature checks, the number of attendees must be in accordance with the size of the location with social distancing, and not exceeding 250 individuals at any one time, and it is compulsory for all to use face masks. According to Senior Minister Datuk Seri Ismail Sabri Copyright $\odot$ GLOBAL ACADEMIC EXCELLENCE (M) SDN BHD - All rights reserved 


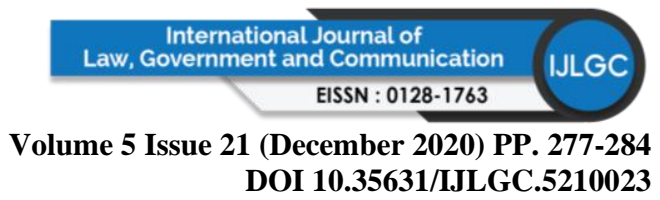

Yaakob, the SPOs for this by-election is based on Act 342 under the Health Ministry to prevent the spread of Covid-19 pandemic. However, the regulations under the Election Commission Act still applies for the duration of the by-election (Bernama, 6 August 2020).

\section{Sabah State Election}

Sabah reported its first positive case was on 12 March 2020 from Tawau District who participated in religious gathering at Sri Petaling, Kuala Lumpur (New Straits Times, 12 March 2020). On $11^{\text {th }}$ September, Sabah recorded the highest case jump of Covid-19 with newer cases passing 300 in more than 3 months (Code Blue, 11 September 2020).

Despite the increased of numbers, Sabah state election took placed on $26^{\text {th }}$ September 2020 to elect all seventy-three (73) members to the $16^{\text {th }}$ Sabah State Legislative Assembly after its dissolution on 30 July 2020. Earlier on $9^{\text {th }}$ August, after the announcement that the election would be held on $26^{\text {th }}$ September, an urgent call was made by members of public to consider postal voting instead of normal voting (South China Morning Post, 9 August 2020). An appeal was also made by 33 Sabah Assemblymen against Governor's consent to dissolve the Sabah State Legislative Assembly; however, such appeal was dismissed by the High Court (New Straits Times, 8 September 2020). Again, on 11 September, the Federal Court also dismissed the appeal to stop the election (The Star, 11 September 2020).

The election was then conducted during the Recovery Movement Control Order (RMCO) due to Covid-19 pandemic; hence the election process was subject to the special SOPs imposed by the Election Commission. On 11 September, the Election Commission issued a press statement on of Covid-19 Prevention Guidelines for the Implementation of Election in Sabah state election (Suruhanjaya Pilihan Raya Malaysia, 11 September 2020). On 23 September second press statement was issued strengthening the earlier guideline and limiting the walkabout in red zone area to two persons only as well as encouraging the online campaign through social media (Suruhanjaya Pilihan Raya Malaysia, 23 September 2020).

Only on $28^{\text {th }}$ September 2020, Senior Minister Ismail Sabri Yaakob announced the Enhanced Movement Control Order (EMCO) on the districts of Lahad Datu, Tawau, Kunak and Semporna between $29^{\text {th }}$ September and $12^{\text {th }}$ October 2020 (The Star, 28 September 2020).

As compared to the two earlier by-elections, Sabah state election has contributed to the increased number of positive cases in Malaysia. According to Director-General of Health, 118 of the new cases reported on $1^{\text {st }}$ October occurred in Sabah, and 31 cases reported in other Malaysian states were linked to those who had returned from Sabah (The Star, 1 October 2020). The Prime Minister also blames Sabah election as among the causes of huge infection surge, an increased to three-digit numbers (South China Morning Post, 6 October 2020). This has been linked to the movement of politicians and voters between Sabah and Peninsular Malaysia.

\section{Batu Sapi By-Election}

Batu Sapi by-election for the parliamentary constituency in Sabah with 32,962 registered voters has been set for $5^{\text {th }}$ December 2020. The Batu Sapi seat was vacant following the death of Datuk Liew Vui Keong on 12 October 2020. However, on 18 November 2020 the Yang diPertuan Agong has declared emergency in Batu Sapi constituency under Article 150 of the Federal Constitution which led to the adjournment of by-election sine die. A press statement issued by the Prime Minister on 18 November 2020 states the reasons of such declaration, among others, factors endangering the public health, lacks of man powers among Election Copyright (C) GLOBAL ACADEMIC EXCELLENCE (M) SDN BHD - All rights reserved 


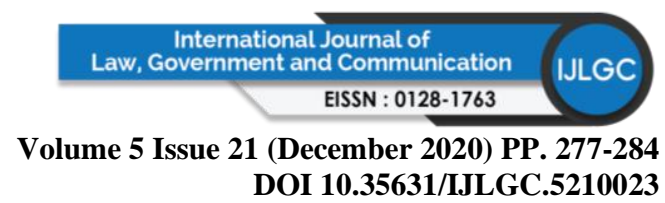

Commission staff to conduct the by-election due to worrying on increased number of Covid19 positive cases in Sabah, prohibition of inter-district movement which includes the Election Commission staff, worrying on Covid-19 infection among the voters, and the social and economic effects to Batu Sapi community if the Covid-19 positive cases is increased after the by-election (Prime Minister's Office, 18 November 2020).

\section{What Is Next?}

Unless Sarawak state governor dissolves the Sarawak state legislative assembly earlier, Sarawak legislative assembly will be dissolved on its own on June 2021, for that matter, Sarawak State Election is automatically due in August 2021.

According to EC Chairman Datuk Abdul Ghani Salleh, new SOPs for elections will be issued which includes three recommendations made by the Ministry of Health, such as no inter-state and inter-district travels, no mass gatherings during campaigns and no house visits. The chairman also reportedly said that the existing SOPs are still in place with the Covid-19 Prevention Guidelines for the Implementation of Election issued by the Election Commission (Bernama, 31 October 2020). Other methods of campaigning announced by the EC are campaign via social media platforms, and candidate can only operate one command center (The Star, 13 October 2020).

Earlier, the Prime Minister was also reportedly said that both upcoming Batu Sapi by-election and Sarawak State election cannot be postponed by virtue of Article 55 of the Federal Constitution and Sarawak State Constitution. The Premier and the former EC Deputy Chairman Datuk Seri Wan Ahmad Wan Omar also said that the only way to delay the elections is through the emergency declaration (Malay Mail, 1 November 2020; The Edge Market, 13 October 2020).

Directorate of Human Dignity, Equality and Governance, Council of Europe on 29 March 2020 issued a statement on "Elections and Covid-19" which concern about elections at the time of a pandemic. Recognizing the efforts made by some governments by adopted emergency measures or declared a state of emergency as allowed by their constitutions, the Council of Europe stresses on importance of fighting against the virus without undermining fundamental freedom and the Rule of law. It is suggested that emergency measures should be limited and strictly target the propagation of the outbreak, so that no substantial freedoms will be sacrificed in favour of more security. Conversely, to hold an election during the Covid-19 pandemic requires careful considerations. 'Specific arrangements will be required for administering such elections and for ensuring the basic tenants of a public debate allowing citizens to be proper informed and to debate the options on offer. Electronic voting or a hybrid version of it combining different types of supports - could be a very credible way out. CM/Recommendation (2017) 5 on standards for e-voting provides an excellent bass for introducing ad hoc voting arrangements with solid security guarantees whilst fully respecting European election standards. Digitalisation of electoral processes can be a viable alternative so as to ensure that democracies continue even in times of pandemics" (Council of Europe, 29 March 2020)

The idea of having a strict electoral process during pandemic have been supported in Article 4 of the International Covenant on Civil and Political Rights (ICCPR). Although Article 21(3) of the Universal Declaration of Human Rights notes that states must have regular, periodic elections (UN General Assembly 1948), Article 4 of the ICCPR meanwhile, states that "in time of public emergency which threatens the life of the nation and the existence of which is Copyright (C) GLOBAL ACADEMIC EXCELLENCE (M) SDN BHD - All rights reserved 


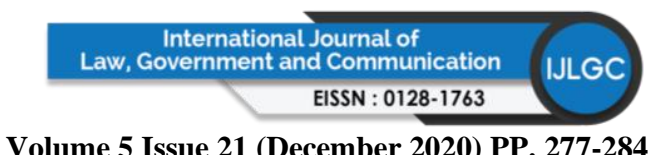

Volume 5 Issue 21 (December 2020) PP. 277-284

DOI 10.35631/IJLGC.5210023

officially proclaimed, the States Parties ... may take measures derogating from their obligations under the present Covenant to the extent strictly required by the exigencies of the situation." International electoral assistance agencies have issued guidance that any emergency provisions must be proportionate, non-discriminatory, temporary, and limited in scope (Ellena and Shein, 2020).

\section{Conclusion}

Article 55 of the Federal Constitution as well as Articles 21 of the Constitution of the State of Sabah and Sarawak clearly indicate that the election shall be conducted within sixty days after the dissolution or vacancy of seat in Parliament or state legislative assembly. This timeframe is a mandatory procedure exercisable by the Election Commission. The last three elections which were conducted during the Covid-19 pandemic not only subject to Election Act 1958 but also complied with special Standard Operating Procedures set by the government. Among the three elections, the Sabah state election showed a great impact by the increased number of Covid-19 positive cases not only in Sabah but the whole Malaysia. This is due to massive movement among the politicians, voters, and supporters during the election process. Although special SOPs has been issued, the inter-district and inter-state movements were said as the main contributors to the spread of the virus throughout Malaysia. Next, one more election is coming. To curb the virus from further spreading, two options are suggested. First, tighten the SOPs by prohibiting inter-district and inter-state movement, limit to online campaign only, and allow only postal or electronic voting. Second, which is the last resort, by declaring emergency under Article 150 of the Federal Constitution after the dissolution of legislative assembly, which allows the executive to suspend the election as happened in Batu Sapi by-election.

\section{References}

Anwarul Yakin. 2007. Legal Research and Writing. LexisNexis: Malaysia.

Bernama, 6 August 2020, 'Covid-19: Improved Chini by-election SOP be used in Slim - Ismail Sabri'. https://www.theedgemarkets.com/article/covid19-improved-chini-byelectionsop-be-used-slim-\%E2\%80\%94-ismail-sabri. Accessed on 2 November 2020

Bernama. 30 May 2020, 'Chini by-election to be benchmark to holding polls during pandemic'. https://www.nst.com.my/news/nation/2020/05/596540/chini-election-be-benchmarkholding-polls-during-pandemic. Accessed on 2 November 2020

Bernama. 31 October 2020. https://www.nst.com.my/news/nation/2020/10/636907/ec-issuenew-election-sop. Accessed on 4 November 2020

CodeBlue. 11 September 2020. 'Sabah's Benteng LD cluster infects 70 Malaysian prisoners, total cases pass 300'. https://web.archive.org/web/20200913051006/https://codeblue.galencentre.org/2020/0 9/11/sabahs-benteng-ld-cluster-infects-70-malaysian-prisoners-total-cases-pass-300/. Accessed on 4 November 2020

Council of Europe. 29 March 2020. https://rm.coe.int/election-and-covid-19/16809e20fe. Accessed on 2 November 2020

Ellena, K. and Erica, S. 30 March 2020. "Emergency Powers and the COVID-19 Pandemic: Protecting Democratic Guardrails". International Foundation for Electoral Systems. https://www.ifes.org/news/emergency-powers-and-covid-19-pandemic-protectingdemocratic-guardrails. Accessed on 15/11/2020

Malay Mail. 1 November 2020. 'Sarawak state election, Batu Sapi by-election cannot be postponed unless emergency declared, says EC's ex-deputy chief'. https://www.malaymail.com/news/malaysia/2020/11/01/sarawak-state-election-batu- 


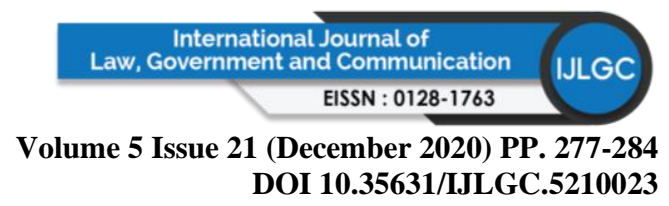

sapi-by-election-cannot-be-postponed-unless-eme/1918275. Accessed on 2 November 2020

New Straits Times. 12 March 2020. 'Sabah's first covid-19 case found in Tawau'. http://www.dailyexpress.com.my/news/148672/sabah-s-first-covid-19-case-found-intawau/. Accessed on 4 November 2020

New Straits Times. 8 September 2020. 'Election is on. Court dismissed appeal over Sabah State Assembly dissolution'. https://www.nst.com.my/news/politics/2020/09/622907/election-court-dismissesappeal-over-sabah-state-assembly-dissolution. Accessed on 2 November 2020

Prime Minister's Office. 18 November 2020. 'Perutusan Khas YAB Perdana Menteri Mengenai PIlihanraya Kecil Batu Sapi, Sabah'. https://www.pmo.gov.my/2020/11/batu-sapi-emergency-no-curfew-no-military-styleadministration-pm-muhyiddin/. Accessed on 19 November 2020

South China Morning Post. 6 October 2020. https://www.scmp.com/week-asia/healthenvironment/article/3104421/coronavirus-malaysia-pm-blames-sabah-electionamong. Accessed on 2 November 2020

South China Morning Post. 9 August 2020. 'Malaysia's Sabah state urged to consider postal voting for election due to corona virus'. https://www.scmp.com/weekasia/politics/article/3096610/malaysias-sabah-state-urged-consider-postal-votingelection-due. Accessed on 2 November 2020

$\begin{array}{lllll}\text { Suruhanjaya } & \text { Pilihan } & \text { Raya } & \text { Malaysia. } & 11\end{array}$ 2020.https://www.spr.gov.my/sites/default/files/KM_BIL\%2061.2020_GARIS\%20P ANDUAN\%20PENCEGAHAN\%20COVID-19.pdf.Accessed on 4 November 2020

$\begin{array}{lllll}\text { Suruhanjaya } & \text { Pilihan } & \text { Raya } & \text { Malaysia. } & 14\end{array}$ https://www.spr.gov.my/sites/default/files/KM\%20BIL\%2042\%202020\%20GARIS\% 20PANDUAN\%20KHAS\%20PRK\%20DUN\%20N.58\%20SLIM\%20PERAK.pdf.

Access on 4 November 2020

Suruhanjaya Pilihan Raya Malaysia. 15 June 2020. https://www.spr.gov.my/ms/pusatmedia/kenyataan-media/prosedur-operasi-standard-sop-khas-bagi-pilihan-raya-kecilprk-dun-n23. Accessed on 4 November 2020

Suruhanjaya Pilihan Raya Malaysia. $19 \quad$ June 2020. https://www.spr.gov.my/sites/default/files/KM25\%20Pemakluman\%20Pindaan\%20S OP\%20Khas\%20Bagi\%20Aktiviti\%20kempen\%20PRK\%20N.23\%20Chini\%20Paha ng.pdf. Access on 4 November 2020

Suruhanjaya Pilihan Raya Malaysia. 23 September 2020 https://www.spr.gov.my/sites/default/files/KM\%20BIL\%2054\%202020\%20GARIS\% 20PANDUAN\%20KHAS\%20PRU\%20DUN\%20SABAH.pdf

The Constitution of the State of Sabah.

The Constitution of the State of Sarawak

The Edge Markets. 31 October 2020. 'Muhyiddin: Batu Sapi, Sarawak elections must be held despite covid-19, unless state of emergency is declared'. https://www.theedgemarkets.com/article/pm-says-batu-sapi-byelection-sarawak-stateelection-cant-be-delayed-despite-covid19-fears. Accessed on 2 November 2020

The Federal Constitution

The Star. 1 October 2020. 'Covid-19: 260 new cases, with Sabah recording 118'. https://www.thestar.com.my/news/nation/2020/10/01/covid-19-260-new-cases-withsabah-recording-118 Accessed on 2 November 2020 


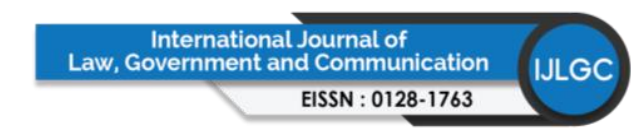

Volume 5 Issue 21 (December 2020) PP. 277-284

DOI 10.35631/IJLGC.5210023

The Star. 11 September 2020. 'Apex court dismisses bid to stop Sabah election'. https://www.thestar.com.my/news/nation/2020/09/11/apex-court-dismisses-bid-tostop-sabah-election accessed on 2 November 2020

The Star. 13 October 2020. 'Batu Sapi by-election on Dec 5 (Updated)'. https://www.thestar.com.my/news/nation/2020/10/13/batu-sapi-by-election-on-dec-5. Accessed on 2 November 2020

The Star. 28 September 2020. 'Four areas in Sabah to be placed under targeted enhanced MCO until Oct $12, \quad$ says https://www.thestar.com.my/news/nation/2020/09/28/four-areas-in-sabah-to-beplaced-under-targeted-enhanced-mco-until-oct-12-says-ismail-sabri. Accessed on 2 November 2020

UN General Assembly. 1948. The Universal Declaration of Human Rights. 